\title{
VARIASI PRONOMINA PERSONA BAHASA BALI DALAM LAYANAN KESEHATAN MASYARAKAT
}

\author{
Ni Made Suryati, Ni Made Dhanawaty, I Made Budiarsa dan I Wayan Simpen
}

\author{
Universitas Udayana
}

\begin{abstract}
Balinese language is divided into two dialects, namely Bali Dataran(DBD), and Bali Aga (DBA) dialect. The DBD variation happens vertically, but not in DBA. Some vocabularies in DBD that are classified into low(TakAlus/TA) are classified as common variants in DBA. This research aims to explore the Balinese personal pronoun variations in DBD which DBA in Sembiran(DS), and Seraya Timur(DST). The results, by applying the dialectology theory and correlation method or metode padan, showed that the personal pronouns of DS and DST varied lexically and phonologically. Lexically, the personal pronoun of first person singular in DBD /(ti)tiyay/(A), /(i)-cay/ and /yay/(TA) was realized as /oke/ and /kaka/ in DS also /(b)-iba/, /uke/, and /wane/ in DST. The second person singular/ragane/(A), /cai// ai/, and /ib /(TA) in DBD, were realized as /cai/, / ai/, and /nko/ in DS also /cai/ and / ai/ in DST; and the third person singular /id /, /dane/(A) and /(i) $\mathrm{y} /(\mathrm{TA})$ in DBD, were realized as /ya/, in DS and DST. Meanwhile phonologically, the realization of phoneme /a/ at the end of the word in DBD was realized as / /, in DS and DST was /a/.
\end{abstract}

Keywords: variation, pronoun, communication, lexical, phonological

\begin{abstract}
Abstrak: Bahasa Bali dibedakan atas dialek bahasa Bali Dataran (DBD) dan dialek bahasa Bali Aga (DBA). DBD memiliki variasi secara vertikal, sedangkan DBA tidak. Kosakata yang dalam DBD tergolong tak-Alus (TA), dalam DBA merupakan varian biasa. Penelitian ini bertujuan membahas variasi pronomina persona tunggal DBD dengan DBA di desa Sembiran (DS) dan Seraya Timur (DST) dalam komunikasi layanan kesehatan masyarakat. Hasil penelitian, dengan menerapkan teori dialektologi dan metode padan ini, menunjukkan bahwa pronomina persona DS dan DST dan DBD bervariasi secara leksikal dan fonologis. Secara leksikal persona I tunggal DBD /(ti)ti ${ }^{\mathrm{y}} \mathrm{an} /, /(\mathrm{i})$-can/ dan /yan/ direalisasikan menjadi /oke/ dan /kaka/ pada DS; /(b)-iba/, /uke/, dan /wane/ pada DST. Pronomina II tunggal /ragane/, /cai/,/ ai/, dan /ib / pada DBD, pada DS /cai/, / ai/, dan /nko/, pada DST /cai/ dan / ai/. Pronomina III tunggal /id /, /dane/ dan /(i) -y / pada DBD, direalisasikan menjadi /ya/ pada DS dan DST. Secara fonologis, fonem /a/ pada distribusi akhir, pada DBD direalisasikan dengan / /, pada DS dan DST dengan /a/.
\end{abstract}

Kata Kunci: variasi, pronomina, komunikasi, leksikal, fonologis 


\section{PENDAHULUAN}

Bahasa Bali (BB) seperti bahasa daerah lainya di Indonesia yaitu bahasa Jawa, Sunda, Madura memiliki variasi baik secara geografis maupun secara stratifikas sosial, Variasi yang dimunculkan oleh kedua pengklasifikasian di atas disebut dengan dialek (Fishman, 1977: 22; Linn (ed.), 1998: 5).Variasi yang didasarkan atas perbedaannya secara geografis disebut dengan istilah geografi dialek atau dialek regional, sedangkan variasi yang ditimbulkan oleh stratifikasi sosial disebut dengan istilah dialek sosial atau sosiolek. Selanjutnya, dialek sosial dapat dibedakan berdasarkan: etnik, umur, jenis kelamin, pendidikan, dan mata pencaharian (Trudgill, 1977).

Secara geografis, berdasarkan hasil penelitian secara garis besarBB dapat dikelompokkan menjadi (1) bahasa Bali Dialek Bali Dataran (DBD) yang tersebar di daerah Bali dataran dan (2) bahasa Bali Dialek Bali Aga (DBA) yang tersebar di daerahdaerah pegunungan pulau Bali, Nusa Penida, Lembongan, dan pulau Serangan (Bawa, 1983). DBA memiliki karakter (fonologis, gramatikal, dan leksikal) yang berbeda dengan DBD.Oleh karena itu, sulit dipahami oleh penutur DBD. Berdasarkan stratifikasi sosial, secara tradisional variasi BB dipengaruhi oleh adanya sistem wangsa yang dimiliki oleh penutur BB. Secara modern, variasi BB juga dipengaruhi oleh stratifikai sosial penutur BB berdasarkan jabatan, kedudukan penutur BB di masyarakat.Variasi BB berdasarkan stratifikasi sosial hanya dimiliki masyarakat DBD.

Dengan adanya variasi BB berdasarkan stratifikasi sosial, BB khususnya pada tataran kata dapat dipilah menjadi beberapa macam.Pembagian kata dalam BB dikemukakan oleh beberapa ahli bahasa, seperti Bagus (1975), Kersten (1957), Naryana (1984), Tinggen (1995).Pembagian yang terakhir dan paling lengkap dikemukakan oleh Suasta (2001), walaupun hanya ditunjukkan melalui kalimat-kalimat.Suryati (2008) menegaskan kembali pembagian kata dalam BB yang untuk selanjutnya istilah kata diganti dengan kruna. Berikut disajikan pembagian kruna BB yang paling lengkap, yaitu (1) kruna alus, dibedakan menjadi (a) alus singgih (asi) digunakan untuk menghormati atau memuliakan yang patut dihormati, (b) alus sor (aso) digunakan untuk merendahkan diri, (c) alus madia (ama) merupakan bentuk singkatan dari bentuk alus, dan (d) alus mider (ami) digunakan baik untuk menghormati maupun merendahkan diri karena bentuk ini hanya memiliki satu bentuk halus; (2) kruna miderdigunakan untuk semua lapisan masyarakat Bali karena bentuk ini hanya memiliki satu bentuk; (3) kruna andap digunakan dalam pergaulan masyarakat pada umumnya, nilai rasanya biasa atau sering disebut kruna kepara/lumrah; (4)kruna kasar biasanya digunakan apabila berkomunikasi dengan keluarga kalangan non tri wangsa, dengan kerahabat dekat, dan ada juga bentuk untuk bertengkar.

Memperhatikan situasi kebahasaan seperti diuraikan di atas, satu kata dalam DBD memiliki beberapa bentuk tergantung pemakainya dan dengan siapa berbicara. Oleh karena itu, satu kata dalam DBD yang merupakan bentuk kasar, dalam DBA merupakan bentuk biasa (karena DBA tidak mengenal variai stratifikasi sosial) sehingga jika petugas (misalnya) yang bertugas di daerah DBA berasal dari DBD dikhawatirkan akan terjadi kesalahpahaman. Misalnya kata iba dalam DBD berarti kamu yang memiliki nilai rasa kasar dan biasanya digunakan dalam konteks bertengkar, sedangkan pada DBA yang ada di Seraya Timur kata $i b a$ atau 'saya'. Jika seorang dokter yang berasal dari DBD bertanya pada pasiennya, “Kenapa Me?(Kenapa Bu?)”Pasiennya menjawab,"Iba bengel".Bisa dibayangkan dokter yang tidak mengenal bahasa pasiennya akan berkata, "Pih kasar sajan munyin pasiene, buina balikanga. Iraga nakonin ia, mabalik I raga orange bengel. Padahal 
kulit I ragane alus. (Pih kasar sekali perkataan pasien, lagi pula dibalik, saya menanyai dia, terbalik malahan saya dikatakan bintik-bintik, padahal kulit saya halus)". Sebenarnya maksud pasien tidak begitu, makna kalimat sebenarnya adalah 'Saya pusing'. Oleh karena itulah, penelitian ini membahas salah satu aspek yang merupakan bagian dari layanan kesehatan masyarakat, yaitu variasi pronomina persona bahasa Bali dengan membandingkan DBD dengan DBA khusus DBA Sembiran (selanjutnya disingkat DS) dan DBA Seraya Timur (selanjutnya disingkat DST). Dengan demikian, ada dua permasalahan yang dibahas dalam artikel ini, yaitu (1) variasi leksikal pronominal personal tunggal bahasa Bali dan pemakaiannya pada layanan masyarakat, (2) variasi fonologis pronominal personal tunggal bahasa Bali. Tujuan penelitian ini adalah untuk mendeskrifsikan variasi pronomina persona tunggal DBD dengan DBA khususnya DS dan DST baik secara leksikal maupunfonologis.Hasil penelitian ini diharapkan dapat dipakai sebagai bekal bagi para medis yang berasal dari DBD jika bertugas di wilayah DBA agar tidak terjadi kesalahpahaman.

Penelitian ini menerapkan teori dialektologi yang didukung oleh teori tradisional dan struktural (Chambers dan Peter Trudgill, 1980: 37-46 dan Petyt, 1980: 171). Teori dialektologi tradisional digunakan untuk menganalisis variasi leksikal. Teori tradisional beranggapan bahwa setiap kata memiliki sejarah sendiri-sendiri. Namun, dalam penelitian ini tidak diuraikan sejarah kata, tetapi hanya dideskripsikan variasi leksikal yang ada dalam pronomina persona Tunggal BB, khususnya DBD dengan DBA (DS dan DST). Sedangkan teori struktural beranggapan bahwa struktural membedakan berbagai tipe perbedaan fonetis sesuai dengan efeknya terhadap struktur fonologis dari dialek-dialek tertentu (Allen dan Linn ed., 1998: 20-24).Yang jelas dialektologi struktural harus memperhatikan relasi struktural dalam setiap dialek dan fungsi unsur-unsur fonetik dalam sistemnya sendiri (Petyt, 1980: 121; Kurath, 1974: 30). Menurut Weinreich dalam suatu bahasa dapat disusun suatu sistem yang lebih tinggi tingkatannya, yang mewujudkan baik kemiripan maupun perbedaan di antara sistem-sistem yang lebih rendah. Sistem yang lebih tinggi disebut diasistematau supersistem; sedangkan sistem yang lebih rendah disebutsubsistem. Jadi ada hubungan hiponimi antara diasistem dan subsistem (Allen dan Linn ed., 1998 22) .

\section{METODE}

Metode yang diterapkan dalam penyediaan data adalah metode pupuan lapangan. Metode ini lebih lanjut dijabarkan menjadi metode simak dan metode cakap (khususnya cakap semuka) (Sudaryanto, 1988: 2-9). Pada tahap penganalisisan data digunakan metode padan dengan teknik dasarnya adalah teknik pilah unsur penentu.Teknik lanjutannya yaitu teknik hubung banding (Sudaryanto, 1993: 13-30; bdk dengan Djajasudarma, 1993: 58). Dalam penerapan metode padan dengan teknik hubung banding menyamakan dan membedakan, masing-masing digunakan untuk memilah unsur-unsur kebahasaan BB, khususnya unsur-unsur yang sama atau unsur yang tidak sama. Dengan menggunakan kedua teknik itu, dapat dipisahkan bentuk-bentuk yang samadan bentukbentuk yang berbeda. Untuk menyajikan hasil penelitian ini digunakan metode formal dan informal, serta kombinasi antara formal dan informal. Metode ini dibantu dengan teknik penyajian induktif dan deduktif yang dipakai secara berkombinasi.Sumber data adalah bahasa lisan yang digunakan oleh penutur DBD dan penutur DS dan DST. Jenis data adalah kualitatif. 


\section{HASIL DAN PEMBAHASAN}

Variasi pronominal persona DBD dengan DBA dikelompokkan menjadi dua, yaitu variasi leksikal dan variasi fonologis.Keduanya diuraikan berikut ini.

\section{Variasi Leksikal}

Berdasarkan data yang berhasil dikumpulkan, variasi leksikal pronomina persona tunggal DBD dengan DBA secara garis besar dapat dikelompokkan menjadi tiga, yaitu (1) variasi pronomina persona pertama tunggal, (2) variasi pronomina persona kedua tunggal, dan (3) variasi pronomina persona ketiga tunggal. Variasi pronominal persona dibahas yang tunggal saja karena bentuk jamak baik pada DBD maupun DBA tidak ditemukan istilah bentuk jamaknya.Ketiga pronomina persona tunggal tersebut disajikan berikut ini.

\section{Variasi Leksikal Pronomina Persona Pertama Tunggal}

Pronomina persona pertama tunggal pada DBD ditemukan beberapa bentuk.Hal itu dapat dilihat berdasarkan data berikut ini.

(1) Titiang jagi lunga ka Denpasar.

/titiyaN jagi luNE kE denpasar/.

'Saya akan pergi ke Denpasar'.

(2) Tiang lakar mulih.

ItiyaN lakar mulih/.

'Saya akan pulang'.

(3) (I)-cang/(I)-yang tusing lakar masuk.

/(i)-caN/(I)-yang tusiN lakar masuk/.

'Saya tidak akan sekolah'.

(4) Kai sing nyak apa ajak iba.

/kai siN ňak apE ajak ibE/.

'Saya tidak mau apa sama kamu'.

Kalau diperhatikan kalimat (1-4), subjek-subjek kalimat tersebut adalah titiang 'saya' pada kalmia (1); tiang 'saya'pada kalimat (2); (i)-cang/(i)-yang 'saya' pada kalimat (3); dan kai 'saya' pada kalimat (4). Dilihat dari makna keempat kata yang menduduki subjek adalah merupakan pronominal persona pertama tunggal.Perbedaan penggunaan kata-kata tersebut disesuaikan dengan siapa yang mengucapkan kalimat-kalimat tersebut dan dengan siapa kalimat-kalumat itu diucapkan.Di samping itu pemakaian masing-masing kata itu juga disesuaikan dengan kata-kata yang mengikutinya.Pronomina persona pertama tunggal titiang pada kalimat (1) merupakan kruna alus sor, digunakan untuk merendahkan diri jika berbicara dengan orang yang patut dihormati. Secara tradisional, umumnya kata ini digunakan oleh non-tri wangsa jika berbicara dengan tri wangsa.Dalam perkembangannya, kata ini juga digunakan jika berbicara dengan orang yang memiliki kedudukan lebih tinggi. Kalau diperhatikan dalam komunikasi, di kalangam tri wangsa kata ini juga digunakan oleh orang yang umurnya lebih kecil jika berbicara dengan orang yang lebih tua.Misalnya, seorang wangsa brahmana berbicara dengan keluarganya yang lebih tua mengatakan: Aji ring dija niki? Titiang kantun ring kampus, malih jebos titiang jagi merika 'Bapak di mana ini? Saya masih di kampus, lagi sebentar saya akan ke`sana. Kata-kata yang mengikuti juga termasuk kruna alus dan kruna mider.

Pronomina persona pertama tunggal pada kalimat (2) adalah tiang 'saya' termasuk kruna alus madia.Bentuk ini merupakan bentuk tidak alus dan tidak kasar atau bentuk pemenggalan dari bentuk alus.Kata-kata yang mengikuti juga tidak begitu alus bentuk 
biasa. Pronomina persona pertama tunggal pada kalimat (3) (i)-cang/(i)-yang 'saya' merupakan bentuk lumrah/kapara, digunakan dalam komuikasi sehari-hari di kalangan masyarakat non tri wangsa. Bentuk ini boleh dikatakan bentuk kasar, tetapi kasar sopan.Kata-kata yang mengikuti juga termasuk bentuk lumrah/kasar hormat.Pronomina persona pertama tunggal pada kalimat (4) merupakan bentuk paling kasar yang umumnya digunakan pada saat bertengkar. Kata-kata yang mengikuti juga ada bentuk kasar sing 'tidak' dan iba 'kamu'dan ada bentuk andap nyak 'mau'.

Pronominal persona DS tidak memiliki variasi sejumlah DBD.Untuk itu berikut disajikan datanya.

(5) Oke glebug uli punyane.

loke glEbug uli puñane/.

'Saya jatuh dari pohon'.

(6) Kaka ngetor'

/kaka NEtor/.

'Saya menggigil'.

Kalau diperhatikan subjek kalimat (5 dan 6), yaitu oke 'saya' pada kalimat (5) dan kaka 'saya' pada kalimat (6).Kedua kata yang berfungsi sebagai subjek merupakan pronominal persona pertama tunggal.Pada DS kedua pronominal persona pertama tunggal tersebut digunakan secara bergantian. Keduanya berstatus sama, tidak ada yang lebih kasar atau lebih halus karena pada masyarakat Sembiran tidak dikenal perbedaan stratifikasi sosial.

Untuk mengetahui pronominal persona pertama pada DST, berikut disajikan datanya.

(7) (B)-iba maňuh.

/biba maňuh/.

'Saya kencing'.

(8) Uke kebus.

luke kEbus/.

'Saya panas'.

(9) Wane nyagur cai.

/wane ňagur cai/

'Saya memukul kamu'

Subjek-subjek kalimat (7-9) adalah /(b)-iba/' saya' pada kalimat (7); /uke/ saya' pada kalimat (8); dan /wane/ saya' pada kalimat (9). Dilihat dari maknanya, ketiga subjek tersebut merupakan pronomina persona pertama tunggal. Sama dengan pada DS, DST juga memiliki variasi pronomina persona pertama tunggal dan variasinya juga tidak digunakan karena perbedaan status sosial.

Berdasarkan data yang sudah diuraikan di atas maka variasi leksikal pronomina persona pertama DBD dengan DS dan DST adalah: pada DBD /titi ${ }^{y} a \mathrm{~h} /$, /ti ${ }^{y} a \mathrm{\eta} /, /(\mathrm{i})-c a \eta /$ /(i)-yaj/ dan /kai/ direalisasikan menjadi /oke/ dan /kaka/ pada DS; /(b)-iba/, /uke/, dan /wane/ pada DST.

\section{Variasi Leksikal Pronomina Persona Kedua Tunggal}

Sama halnya dengan pronominal persona pertama, pronominal persona kedua DBD juga memiliki variasi berdasarkan stratifikai sosialnya.Hal itu dapat diketahui berdasarkan data yang disajikan berikut ini.

(10) Jerone saking dija?

/jErone sakiN dijE?

'Kamu dari mana'.

(11) Ragane ten milu luas? 
Iragane tEn milu luwas?/

'Kamu tidak ikut pergi?

(12) Cai nyemak pipis memene? /cai ňE mak pipis memene?/

'Kamu (laki-laki)mengambil uang Ibu?'

(13) Nyai ngatehang I Bapa ke rumah sakit nah! /ñai NatE haN I bapE kE rumah sakit nah!/

'Kamu (wanita) mengantar bapak ke rumah sakit ya!'

(14) Iba ane ngranayang kai merebat ajak timpal. /ibE ane NranayaN kai mErEbat ajak timpal/

'Kamu yang menyebabkan saya bertengkar dengan teman'.

Subjek-subjek kalimat (10-14) adalah jerone 'kamu;pada kalimat (10) digunakan apabila komunikasi terjadi dengan orang yang baru dikenal.Kata-kata yang mengikuti juga termasuk kruna ami (saking) dan mider (dija). Subjek pada kalimat (11) ragane 'kamu' termasuk bentuk madia; subjek pada kalimat (12) adalah cai 'kamu' merupakan bentuk andap dan digunakan untuk laki-laki, kata-kata yang mengikuti juga bentuk andap; subjek pada kalimat (13) nyai 'kamu' merupakan bentuk andap yang digunakan untuk perempuan dan kata-kata yang mengikuti juga bentuk andap; dan subjek pada kalimat (14) iba 'kamu merupakan bentuk kasar yang digunakan dalam konteks bertengkar dan kata-kata yang mengikuti juga bentuk kasar dan andap.Jika diperhatikan, kelima subjek kalimat tersebut bermakna 'kamu' (persona kedua tunggal). ini.

Pronomina persona kedua tunggal Desa Sembiran disajikan berdasarkan data berikut
(15) Ngko ngigel. /Nko NigEl/
'Kamu menari'.
(16) Cai tegeh /cai $t E g E h /$
'Kamu (Laki-laki) tinggi'.
(17) Nyai dadi guru? /ňai dadi guru?/
'Kamu (wanita) menjadi guru?'

Kalau diperhatikan subjek-subjek kalimat (15-17) pada DS, semuanya bermakna kamu sebagai pronominal persona tunggal. Variasi pronomina persona tunggal pada DS digunakan dengan status sama (tidak ada alus kasar). Jika dibandingkan dengan DBD, kedua persona tunggal nyai dan cai termasuk bentuk andap.

Pronomina persona tunggal pada dialek Seraya Timur dapat diketahui berdasarkan data yang disajikan berikut ini.

(18) Cai nebek uke.

\section{/cai nEbEk uke/}

'Kamu (laki-laki) menusuk saya'

(19) Nyai maang anak ento biu.

/ňai maaN anak Ento bi ${ }^{y} u$ /

'Kamu (wanita) member orang itu pisang'. 
Kedua subjek pada kalimat (18 dan 19) yaitu cai dan nyai merupakan pronominal persona kedua tunggal karena maknanya sama adalah 'kamu' . Penggunaan kedua kata tersebut juga sama dengan pada DS.

Berdasarkan uraian di atas maka dapat dikatakan bahwa variasi pronominal persona kedua tunggal BB /jerone/, /ragane/, /cai/,/ ai/, dan /ibə/ pada DBD, pada DS direalisasikan menjadi /cai/, /nai/, dan /ొko/, pada DST direalisasikan juga menjadi /cai/ dan /nail.

\section{Variasi Leksikal Pronomina Persona Ketiga Tunggal}

Variasi pronomina persona keiga tunggal DBD ditemukan tiga buah. Ketiganya digunakan berbeda tergantung pada yang menggunakan. Berikut disajikan datanya.

(20) Ida lunga saking i nuni semeng.

/idE luNE sakiN i nuni sEmEN/

'Beliau pergi dari tadi pagi..

(21) Dane sane jagi muput upacara puniki.

/dane sane jagi muput upEcarE puniki/

'Beliau yang akan menyelenggarakan upacara ini'.

(22) Ia suba tamat SMA jani.

$/ i^{y}$ E subE tamat SMA jani/

'Ia sudah tamat SMA sekarang'.

Pronomina persona ketiga tunggal pada kalimat (20) adalah ida 'beliau'. Bentuk ini biasanya diguakan untuk menyebutkan tri wangsa yang dihormati. Kata-kata yang mengikuti juga termasuk kruna alus. Begitu juga pronomina persona ketiga tunggal pada kalimat (21) adalah dane 'beliau', digunakan untuk menyebutkan non tri wangsa yang patut dihormati, seperti Jero Mangku, Guru. Pronomina persona ketiga tunggal pada kalimat (22) adalah ia merupkan bentuk andap/ kasar biasanya digunakan di kalangan non tri wangsa.

Untuk DS dan DST, pronomina person tiga tunggal sama hanya memiliki satu buah, yaitu ya'dia'. Penggunaannya dalam kalimat disajikan berikut ini.

(23)Ya nuturang unduk memenane (DS)

/ya nuturaN unduk memenane/"

'la menceritrakan tentang ibunya'.

(24)Ya metaang unduk memennya (DST)

/ya mEtaaNunduk memenňa/

'la menceritrakan tentang ibunya'.

Pronomina persona ketiga tunggal DS adalah subjeknya yaitu ya ' dia', begitu juga pada DST pronomina persona ketiga tunggalnya juga terletak pada subjek kalimatnya yaitu ya 'ia.

Dengan demikian, variasi pronomina persona ketiga tunggal BB adalah /id /, /dane/ dan $/(i)-y \partial /$ pada DBD, direalisasikan menjadi /ya/ pada DS dan DST.

\section{Variasi Fonologis Pronomina Personal Bahasa Bali}

Berdasarkan uraian variasi leksikal pronomina persona DBD dengan DS dan DST, maka ditemukan adanya dua variasi fonem. Kedua variasi tersebut adalah sebagai berikut.

1) Fonem /E/ pada DBD direalisasikan menjadi fonem /a/ pada akhir kata pada DS dan DST. Contoh: /iyE/ 'ia' (DBD) menjadi /ya/ pada DS dan DST.

2) Fonem /o/ pada DS direalisasikan menjadi /u/ pada DST pada awal suku kata. Contoh: pronomina persona pertama tunggal /oke/'saya' DS menjadi /uke/'saya pada DST. 


\section{SIMPULAN}

Berdasarkan uraian di atas, dapat ditarik beberapa kesimpulan mengnai variasi pronomina persona $\mathrm{BB}$.

1) Secara leksikal pada DBD ditemukan variasi yang disebabkan oleh stratifikasi sosial,

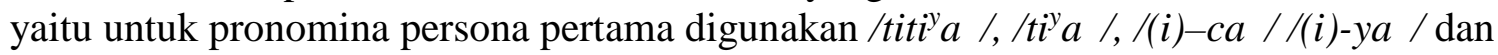
/kai/; pronominal persona kedua tunggal ditemukan bentuk /jerone/, /ragane/, /cai/,/ ai/, dan /ibə/; variasi pronomina persona ketiga tunggal adalah /id /, /dane/ dan /(i) - yə/.

2) Secara georfafis, variasi leksikal DBD pada kesimpulan 1) direalisasikan menjadi: variasi pronomina persona pertama tunggal loke/ dan /kaka/ pada DS dan /(b)-iba/, luke/, dan /wane/ pada DST; variasi pronomina persona kedua tunggal direalisasikan menjadi: /cai/, / Mail, dan /łko/ pada DS serta /cai/ dan /nail pada DST; variasi pronomina persona ketiga tunggal direalisasikan menjadi/ya/ pada DS dan DST.

3) Secara fonologis, variasi pronomina persona antara DBD dengan DS dan DST ditemukan sebagai berikut. (1) Fonem /E/ pada DBD direalisasikan menjadi fonem /a/ pada akhir kata pada DS dan DST ; (2) Fonem /o/ pada DS direalisasikan menjadi /u/ pada DST pada awal suku kata.

\section{DAFTAR PUSTAKA}

Allen, Harold B. dan Michael Linn D. (Ed.) . 1998. Dialect and Language Variation. Academic Press, INC: Orlando, San Diego, New York, Austin, London, Montreal, Sydney, Tokyo, Toronto.

Bagus, I Gusti Ngurah. 1975/1976. “Tingkat-Tingkat Bicara dalam Bahasa Bali”. Denpasar: Proyek Penelitian Bahasa dan Sastra Indonesia dan Daerah Pusat Pembinaan dan Pengembngan Bahasa, Departemen Pendidikan dan Kebudayaan.

Bawa, I Wayan.1983. "Bahasa Bali di Daerah Propinsi Bali: Sebuah Analisis Geografi Dialek". Disertasi. Jakarta: Fakultas Sastra Universitas Indonesia.

Chambers, J. K. dan Peter Trudgill. 1980. Dialectology. Cambridge-London-New YorkNew Boshola-Melbourne-Sydny: Canbridge University Press.

Djajasudarma, T. Fatimah. 1993. Metode Linguistik: Ancangan Metode Penelitian dan Kajian. Bandung:Eresco.

Fishman, J. A. 1977. Sosiolinguistik: Sebuah Pengantar Singkat. Terjemahan Barhaya Ali. Jakarta: Pusat Pembinaan dan Pengembangan Bahasa Departemen Pendidikan dan Kebudayaan.

Kurath, Hans. 1974. Studies in Area Linguitics. Blomington and London: Indiana University Press.

Lin, Michael D (ed.). Handbook of Dialects and Language Variation. Second Edition. San Diego, London, Boston, New York, Sydney, Tokyo, Toronto: Academic Press.

Narayana, Ida Bagus Udara. 1984. "Tingkatan Anggah-Ungguhing Basa bali” dalam Jurnal Widya Pustaka Th. I, Nomor 1. Denpasar: Fakultas Sastra Universitas Udayana.

Petyt, K.M. 1980. The Study of Dialect: An Introduction to Dialectology. London: Andre Deutsch.

Suasta, Ida Bagus Made. 2001. "Rasa Basa Basa Bali”. Prosiding. Kumpulan Makalah Kongres Bahasa Bali V. Denpasar: Fakultas sastra Unud, Program S2, S3 Linguistik dan Kajian Kebudayaan Unud dan IKIP Ngeri Singaraja, 13-16 November 2001. 
Sudaryanto. 1988. Metode Linguistik Bagian Kedua: Metode dan Teknik Pengumpulan Data. Yogyakarta: Gajah Mada University Press.

Sudaryanto . 1993.Metode dan Aneka Teknik Analisis Bahasa Pengantar Penelitian Wahana Kebudayaan. Yogyakarta; Duta Wacana University Press.

Trudgill, Peter. 1977. "Sosiolinguistik: Sebuah Pengantar". Terjemahan Johannis Mongoting. Jakarta: Pusat Pembinaan dan Pengembangan Bahasa Departemen Pendidikan dan Kebudayaan. 